DOI 10.37882/2223-2982.2021.06.33

\title{
ОТРАСЛЕВЫЕ ВЫСТАВКИ В СЕЛЬСКОМ ХОЗЯЙСТВЕ И ПИЩЕВОЙ ПЕРЕРАБОТКЕ ВО ВТОРОЙ ПОЛОВИНЕ ХІХ-НАЧ. ХХ ВВ. В РОССИИ
}

\section{INDUSTRY EXHIBITIONS IN AGRICULTURE AND FOOD PROCESSING IN THE SECOND HALF OF THE XIX TH - BEGINNING OF THE XX TH CENTURIES IN RUSSIA}

\section{S. Rogatko}

Summary: This article analyzes general agricultural exhibitions, and then distinguishes them from industry exhibitions in agricultural production and food processing, shows their transformation from "representative" exhibitions in the initial post-reform period to exhibitions in the 1880-90s. with transformation of the exhibition infrastructure and development of the idea of accumulation and dissemination of production experience and knowledge. Throughout analysis is given to some industry exhibitions in horticulture and vegetable growing, on the basis of which the international forums were help on. The general structure and statistics of agricultural exhibitions with food processing in the light of agrarian reforms at the beginning of the $X X$ century is shown.

Keywords: general and branch agricultural exhibitions, "representative" exhibitions, exhibitors and exhibits, international forums.

\author{
Рогатко Сергей Александрович \\ К.и.н., Российский комитет по истории и философии \\ науки и техники РАН \\ rogatko1@yandex.ru
}

Аннотация: В данной статье проводится анализ общих сельскохозяйственных, а затем выделения их них отраслевых выставок в сельскохозяйственном производстве и в пищевой переработке, показана трансформация от «представительных» выставок в начальный пореформенный период к выставкам в 1880-90-е гг. с изменением выставочной инфраструктуры и развития идеи накопления и распространения производственного опыта и знаний, дается анализ некоторых отраслевых выставок в садоводстве и овощеводстве, на базе которых проводились международные форумы. Показана общая структура и статистика сельскохозяйственных выставок с пищевой переработкой в свете аграрных реформ в начале XX в.

Ключевые слова: общие и отраслевые сельскохозяйственные выставки, «представительные» выставки, выставочные экспоненты и экспонаты, международные форумы.
$\mathrm{B}$ ходе развития капиталистических отношений в первой половине XIX в. сельскохозяйственные выставки, на которых участвовали главным образом помещичьи хозяйства и государственные крестьяне со всем своим спектром сельскохозяйственного производства и пищевой переработки, явились неотъемлемой частью деятельности сельскохозяйственных обществ. Указом Николая І от 1842 г. было положено начало сельскохозяйственных выставок в России [1]. К первым выставкам, которые более имели «представительный характер» прибегали сельскохозяйственные окружные съезды, позже губернские и районные и, кроме этого, гораздо позднее съезды некоторых пищеперерабатывающих отраслей. Инициаторами наиболее значимых выставок выступали Императорское Вольно-экономическое общество (ИВЭО), Императорское Общество сельского хозяйства (ИОСХ) Южной России, а также губернские и уездные общества, Министерство государственных имуществ (МГИ), генера-губернаторства и земские учреждения. Основным достижением первых выставок в 40-е гг. XIX в. было то, что они из замкнутого местного волостного, уездного и губернского аграрного пространства вывели на всеобщее обозрение многие новейшие технологиче- ские приемы, методы и формы хозяйствования, ставшие реальностью в передовых помещичьих экономиях.

Для расширения передачи опыта и знаний с 1850 г. МГИ приняло Нормальные правила, по которым сельскохозяйственные выставки стали проводиться в каждой губернии [2, С.274]. Реформы 1860-х гг. внесли свои изменения в проведение сельскохозяйственных выставок. Если в дореформенное время среди экспонентов кроме помещиков на них весьма широко участвовали государственные крестьяне, то после упразднения опеки в 1866 г. над бывшими государственными крестьянами в лице Департамента Земледелия МГИ и передачи их в губернские и местные учреждения по крестьянским делам, многие крестьяне перестали появляться на выставках [3]. Основная причина крылась в переходном периоде, когда крестьянские хозяйства не сформировались как полноценные участники рынка сельскохозяйственного производства и переработки. В этот период Департамент Земледелия МГИ, а затем и Временный отдел по земельному устройству государственных крестьян уже не могли силой заставить особенно даровитых и относительно уже свободных крестьян принимать 
участие в выставках. Их теперь интересовали местные «временные выставки» и ярмарки для реализации своих продуктов. Таким образом представительные выставки постепенно сходили на нет. На их смену пришли местные уездные и межрайонные выставки. Как правило их организовывали земские сельскохозяйственные отделы с учетом агрономической, производственной и торговой местной специфики. В 70-80-е гг. Департамент Земледелия МГИ старался по-прежнему помогать средним и крупным выставкам сельских произведений в необходимых средствах, оформлении помещений, в развитии общероссийских стандартов по образцам лучших европейских выставок. По новым правилам 1869 г. в распорядительные комитеты по устройству выставок кроме земских чиновников теперь входили и представители местных сельскохозяйственных обществ. Особая роль по проведению всероссийских выставок сельскохозяйственных произведений стала принадлежать управляющим палатами государственных имуществ в Губернских Комитетах, которые заботились об участии в выставках государственных крестьян. При этом принцип обязательного ежегодного устройства очередной выставки был заменен на принцип целесообразности организации выставки в зависимости от условий и целей проведения выставки. Всего с 1861 по 1887 гг. в Российской империи было организовано до 350 общих сельскохозяйственных и отраслевых выставок [2, С.275].

Заметим, что отраслевая структура экспонентов на выставках уже предусматривалась начиная с первых Всероссийских сельскохозяйственных выставок 1850 и 1860 гг. проходивших в Петербурге. Например, на Всероссийской сельскохозяйственной выставке 1864 г. в Москве экспоненты делились на специализированные отделы: I отдел - предметы земледелия, II отдел - предметы скотоводства, III и IV отделы - сельская заводская и сельская ремесленная промышленность представлявшая продукты переработки фабрично-заводского и сельскохозяйственного типа, V отдел - машины, орудия и снаряды как отечественного производства, так и иностранного для перерабатывающих отраслей: мукомолья, маслоделия, свекловодства и пр.)[4,С.1-248] Все экспоненты по отделам носили представительный территориальный характер размещения. Кроме того, отдельно были представлены экспоненты Финляндии. Надо сказать, что в плане регионального представительства, многие экспонаты выставки были совершенно не сбалансированы и неравномерны по своей специфики. Некоторые экспонаты, такие как, например, зерновые культуры, так хаотично были разбросаны по выставочному манежу, что не могло не создать явные затруднения для работы специалистов и экспертов. Основные причины такого положения в устройстве выставочных отделов крылись в неправильной группировке по сортам и видам растений, плодов и других переработанных продуктов. К этому добавлялась низкая информационная обеспеченность о представленных экспонатах и экспонентах. По этому поводу знаменитый аграрий А.В. Советов об устройстве I отдела Московской выставки 1864 г. писал: «Она (выставка - nрим. aвm.) указала нам немало новых деятелей, напомнила о старых, но забытых нами, и вообще внесла довольно сельскохозяйственных сведений; но до них надобно было добираться разными, довольно хлопотливыми путями, пользуясь или личным знакомством с экспонентами, или теми короткими заметками, которые они прилагали при отправке своих произведений, или, наконец, прибегая и к собственным наблюдениям и соображениям» $[4, C .5]$. В Комиссии по устройству Московской выставки еще в 1863 г. выдачу наград связывали не столько с намерением экспонента «блеснуть своими произведениями, приготовленными нарочно для выставки», сколько в оценке его стремления к улучшению ведения своего хозяйства[5]. Поэтому Комиссия видела основные способы в достижении цели выставок в следующем: 1) в условиях, на которых допускались сами сельскохозяйственные и переработанные продукты на выставку; 2) в способах экспертизы; и 3) в способах сбора экспонатов на выставку [5].

Можно сказать, что указанные недостатки на выставках 60-х гг. XIX в. не способствовали на практике к проведению идеи улучшения экономического и технологического состояния хозяйств и отраслей в целом и, кроме этого, постоянному обмену производственным опытом среди экспонентов из всех районов страны. На деле выходило так, что «представительная» идея - выделение и награждение экспонентов медалями по-прежнему, как и в первой половине XIX в., главенствовала на выставках.

Новым этапом структурного преобразования Всероссийских сельскохозяйственных выставок стали 80-е гг. XIX в. В 1887 г. в Харькове под эгидой Харьковского Общества сельского хозяйства была организована четвертая очередная (первая «провинциальная») Всероссийская сельскохозяйственная выставка. Благодаря организационной помощи Департамента земледелия и сельской промышленности МГИ, финансовой помощи Министерства финансов, Харьковского городского общества, Харьковского губернского земства, Харьковского земельного банка, Департамента уделов, других общественных организаций, частных пожертвований на медали, выставка из отраслевой по скотоводству превратилась в полномасштабную выставку сельских произведений и продуктов переработки [6,C.II]. Кроме традиционных для всероссийских выставок отделов, связанных с земледелием и скотоводством, на выставке были представлены специальные отделы, где были представлены экспонаты перерабатывающих отраслей, до этого почти не встречавшихся на выставках. Так в I «Животноводство» были представлены продукты, приспособления и механизмы связанные с птицеводством, рыбоводством, пчеловодством и шелководством. Во 
II отделе «Произведения скотоводства» в специализированном подотделе «Молочно-хозяйственном демонстративном» экспонировались молоко свежее и топленое, молоко сгущенное, кумыс, кефир, молочная мука (сухое молоко). Кроме этого, традиционные продукты более глубокой переработки - масло и сыры. А также приборы, принадлежности молочного хозяйства; приборы для научного исследования и для контроля молока; передвижные маслодельни и сыроварни. В подотделе, который экспонировал переработанные продукты скотоводства, демонстрировались: шерсть, волос, копченое и вяленое мясо всех видов домашних животных, а также мясные консервы, сало, жиры, альбумин, желатин, клей, рог, костяную питательную муку и др. B IV отделе демонстрировались продукты виноградарства и виноделия. В V отдел специализировался на экспонатах по так называемым в то время «сельскохозяйственным техническим производствам»: муке, крахмале растительных маслах, спирте и сахаре [6, C.I]. Таким образом в 51 павильоне на Харьковской выставке впервые были представлены продукты переработки почти всех пищеперерабатывающих отраслей. Это вызвало у А.В. Советова восторженный отзыв, в котором говорилось, что «Харьковскую выставку можно назвать даже грандиозною» [6, C.IX]. Такая детальная специализация выставки помогала экспертам более тщательно оценивать не только возможности того или иного хозяйства по производству и переработки сырья, отмечать их достоинства, но и находить узкие, проблемные места в структуре хозяйства, выявлять недостатки, ставить задачи по их преодолению и главное способствовать более быстрому распространению опыта среди экспонентов. Этому также помогала аграрная наука, которая также была представлена на выставке.

Ранее уже отмечалось, что в пореформенное время отраслевые выставки устраивались общественными организациями и государственными учреждениями (МГИ, Минфином и земством) почти по всем направлениям сельскохозяйственного производства и переработки. Тематика выбиралась в зависимости от отраслевой специфики каждого региона. Чаще всего организовывались выставки по животноводству, птицеводству, садоводству и огородничеству, полеводству и пчеловодству. Также на каждой Всероссийской художественно-промышленной выставке 1882 г. в Москве или в 1896 г. в Нижнем Новгороде при отсутствии специализированных отделов, устроители все-таки старались демонстрировать успехи сельского хозяйства и пищевой переработки. Особенно это касалось традиционного земледелия. Пожалуй, главным из разделов на этих выставках среди перерабатывающих отраслей был отдел посвященный мукомольному машиностроению. И это не удивительно, ибо в 70-90-е гг. XIX в. эта отрасль являлась примером высокотехнологической отрасли пищевой переработки. А также машиностроению в других перерабатывающих отраслях. Например, на Всероссийской выставке 1882 г. в
Москве экспонировались первоклассное оборудование раструсных и вальцевых ржаных и крупчатных мельниц Товарищества «Антон Эрлангер и Ко». Петербургский механический завод экспонировал новейшие гидравлические прессы для макаронных фабрик. На Нижегородской выставке 1896 г. петербургская фирма «Кулинар» (основана в 1893 г.) экспонировала большое разнообразие макаронных изделий: ржаные, сливочные, шоколадные (десертные), яичные макароны (лапша), макароны из шотландского овса под названием «Силач» и многие другие.

Чтобы привлечь капиталы в мукомольную отрасль и распространять достижения в мукомольном деле благодаря деятельности Совета Съездов мукомолов России в 1909 г. Петербурге была организована Первая всероссийская мукомольная выставка [7]. Экспонентами выставки стали все крупнейшие и даже средние и мелкие мукомольные предприятия почти из всех мукомольных районов страны. Кроме продукции таких знаменитых нижегородских мукомолов, как Я.Е. Башкирова, саратовских Борель, Рейнеке, Степашкин и Шмид, киевлян Жуковского, Костецкого и Тритшель, сибиряка Фуксмана, петербургских предпринимателей Торгового дома Роттермана и Петрова, и многих других на выставке особым интересом пользовались мукомольная техника европейских заводов. В основном это было оборудование заводов: Лютер, Бр. Зекк, Амме, Гизиге и Конеген, Даверио, Каплер и других иностранных производителей. Большинство крупнейших российских мельниц оснащались машинами этих заводов. Единственным машиностроительным заводом для городских мельниц в России долгое время считалось Товарищество «Добровых и Набгольц», имеющее свои заводы в Москве и Н. Новгороде с представительствами в городах многих мукомольных районов. Этот завод весьма удачно перенимал изобретения европейских конструкторов, (в частности, сдвоенный рассев Конегена) и на этой основе создавал свои, собственные машины. А такая русская фирма К.Ю. фон Денвера и Жуковского производила высококачественные конструкции жерновых поставов для мельниц сельскохозяйственного типа, а также нефтяные двигатели.

Как известно в пореформенное время все больший интерес помещичьи и возникавшие крестьянские хозяйства проявляли к таким отраслям, как как пчеловодство, садоводство и огородничество. Благодаря деятельности Императорского российского общества садоводства (ИРОС, созданное в 1858 г.) еще в 1869 г. в была организована первая в России Международная выставка предметов садоводства. Среди экспонентов из 11 стран выделялись выставочные отделы Англии, Бельгии, Германии, Голландии и Греции. Успех выставки говорил сам за себя. На открытии выставки побывали император Александр II с семьей и главы дипломатического корпуса. Особым интересом пользовались экспонаты цветущих 
и лиственных растений, овощи, переработанные плоды в консервированном виде, комнатное, оранжерейное и воздушное садоводство, а также садовые орудия и принадлежности, проекты садов и оранжерей. Всего 750 экспонатов [8]. Следующая выставка 1884 г. удивила посетителей своим многообразной и обширной экспозицией, которая уже не могла разместиться в Манеже. Поэтому решено было построить специальные теплицы, а также особый павильон для коллекции бразильского кофе. Здесь же был обустроен прекрасный сад под открытым небом. Для развития садоводства и огородничества и переработки плодов большое значение имели и всероссийские и международные выставки ИРОС, которые проводились в Михайловском манеже в Петербурге в 1890 и 1908 гг., а также в Таврическом дворце в 1899 и 1903 гг. $[9,10]$.

Несомненно, что опыт Харьковской Всероссийской общей сельскохозяйственной выставки 1887 г. и деятельность ИРОС с его выставками по садоводству вызвали у многих купцов и предпринимателей интерес к всесторонней переработке плодов садоводства и огородничества. Этот интерес был замечен и Министерством государственных имуществ, которое в 1886 и в 1887 гг. на сельскохозяйственных выставках в Петербурге, Симферополе, Харькове, Москве и Киеве организовали публичные мастер-классы сушки фруктов и овощей, которые проводились с лекциями и чтениями. В октябре-ноябре 1888 г. по инициативе ИВЭО совместно с МГИ была организована Первая Всероссийская выставка сушеных овощей и фруктов в Петербурге [11, С.1]. Среди сушенных фруктов выделялись экспонаты из плодов яблок, груш, слив (чернослив), абрикосов, персиков, а также ягод - малины, земляники, черники, шелковицы, винных ягод (инжира), плодов вишни, винограда (изюм), грецких орехов и грибов. Отдел овощей кроме традиционного уже в то время сушеного картофеля и моркови, был представлен экзотическими сушеным помидором, а также овощными смесями и смесями кореньев для супов, зеленый горошек, цветная капуста, сушеные брюква, кольраби, зелень сельдерея и др. Большинство смесей были представлены в виде консервов в красочной упаковке. Известный агроном, инспектор сельского хозяйства при МГИ и член Ученого комитета МГИ, В.В. Черняев, писал, что «русские сушеные овощи по своим качествам нисколько не уступают пресловутым французским, не говоря о немецких, тем более что иностранный товар поступает к нам не свежий, а лежалый - годовалый, т.е. такой, который заграницею остается непроданным» [11, C.4]. Стоит заметить, что на том этапе развития садоводства и огородничества в России, и это было показано на выставке, консервное производство в этой отрасли имело достаточно много проблем. Среди главных - технологические и торговые стандарты качества. На выставке в Петербурге участвовало всего 23 экспонента, в основном помещики, овощеводы-мещане, сельскохозяйствен- ные школы из разных губерний и купцы южных, юго-западных и черноземных губерний России.

Среди отраслевых выставок 90-х гг. выделяется организованная Императорским Российским обществом плодоводства (ИРОП, организовано в 1891 г.) Международная выставка плодоводства, огородничества и виноделия в Петербурге в 1894 г. На ее проведение МГИ выделило 60 тыс. руб. Главными экспонентами на выставки были предприниматели из Франции, Австро-Венгрии, Бельгии, Германии, Греции, Дании, Италии, Швейцарии и Китая. В Михайловском манеже и прилегающей территории была размещена сама экспозиция [8]. Затем в 1912 г. в Петербурге была организована Всероссийская выставка пчеловодов, садоводства, огородничества и соприкасающихся с ними отраслей [12]. Проведение постоянных выставок в этих отраслях требовали структурного и методологического совершенствования. А для этого требовались дополнительные площади. Поэтому идея строительства постоянного выставочного здания для отраслевых выставок по садоводству и огородничеству возникала на совещаниях в ИРОС еще в 1860 г. Лишь через 50 лет в 1910 г. к этой идее вернулись при подготовке очередной Международной выставки 1913 г. На это раз кроме совершенствование экспозиционной деятельности устроители прибегли к чисто экономическому фактору, без которого развитие отрасли не имело успеха. В апреле 1914 г. здание с небольшими недоделками было в основном закончено. Здание на тот период отвечало всем требованиям европейских выставочных стандартов. Над главным залом нависал прозрачный стеклянный фонарь. Были сооружены специальные пандусы для выгрузки кадок с растениями, а также оборудованы помещения для лекций, кабинеты и служебные помещения для ИРОС. В мае 1914 г. в недостроенном здании была размещена Международная юбилейная выставка садоводства. Ее покровительствовал император Николай II. Кроме нового здания, выставка проходила также и в Таврическом саду [8].

Во второе девятилетие XX в. выставочная деятельность охватила почти все регионы России. Достаточно сказать, что по отчетам Департамента земледелия Главного управления землеустройства и земледелия (ГУз и 3) во всех губерниях Российской империи, включая Варшавское генера-губернаторство, Сибирь, Кавказ и Туркестан, прошла 1021 общая сельскохозяйственная выставка, на которых были представлены практически все виды сельскохозяйственного производства, торговли и пищевой переработки. Кроме этого, в тот же период было организовано 155 отдельных выставок по птицеводству (Подсчитано авт.) [13].

Анализ статистики по отчетам Департамента земледелия Главного управления землеустройства и земледелия (ГУ и 3) в 1913 г. показывает, что в разделе «Общие 
сельскохозяйственные выставки» указывались все отраслевые направления по сезонам: животноводческие, рогатого скота, конские, пчеловодства, плодоводства, садоводства и огородничества, семян, выставки разных наименований (машинные, льноводческие, переработки цикория и пр.) . Отдельно были показаны выставки по птицеводству. Если по сведениям на 15 февраля 1914 г. планировалось провести всего 692 выставки (подсчитано авт.) [14], то по данным на 1 мая 1913 г., в России уже было организовано 735 сельскохозяйственных выставок, в том числе по птицеводству (подсчитано авт.) [13]. То есть на 1914 г. планировалось увеличить проведение выставок, если бы не помешала война. Всего же общее число сельскохозяйственных выставок в 1913 г. по официальным данным ГУЗ и 3 превысило 1026, среди которых 14 крупных, которые представляли всероссийский интерес [15]. Все это еще раз говорило о том, что выставочное дело развивалось по мере реформирования всех сельскохозяйственных отраслей и всех типов пищевой переработки.

Как видим, идея накопления и распространения производственного опыта и проведения общих и отраслевых сельскохозяйственных выставок появилась в России не сразу. В начале пореформенного периода выставки имели представительный и коммерческий характер. По мере развития сельских хозяйств и перерабатывающих предприятий выставочные экспоненты все больше прибегали к просветительским формам: чтениям, лекциям и публичным показательным испытаниям, тем самым распространяя свой опыт и знания. В пореформенный период отраслевые местные выставки (губернские, районные) являлись практической связью между земством, общественными организациями, производителями и местным населением. В период аграрных реформ в начале XX в. отраслевые выставки являлись частью работы общественных сельскохозяйственных организаций на всех уровнях. Выставки также являлись конкурентной средой для изменяющихся экспонентов: помещиков, зажиточных крестьян, купцов, городских и сельских предпринимателей-переработчиков, кооператоров, сельскохозяйственных обществ. При этом «представительная» форма организации выставок, которая подразумевала получение наград и призов, составление выставочных рейтингов и коммерческую выгоду вполне могла уживаться с бескорыстным распространением опыта и знаний. Выставочный опыт в таких отраслях, как птицеводстве, садоводстве, овощеводстве и переработке плодового сырья стал основой для проведения в России международных форумов. Международные выставки на регулярной основе стали хорошим стимулом для постоянного обмена знаниями и опытом между аграриями-теоретиками и специалистами-практиками из разных стран. В свою очередь авторитет наших отраслевых международных выставок способствовал поднятию престижа русских сельских производителей и купцов на многих европейских рынках.

\section{ЛИТЕРАТУРА}

1. Полное собрание Российского законодательства (ПСЗ РИ-2). T.XVII. № 16307. - Декабря 9 (1842). Именный, объявленный Министром Государственных Имуществ. - 0 учреждении по губерниям выставок произведения земли, скота и произведения сельских ремесел.

2. Пономарев Н.В. Исторический обзор правительственных мероприятий к развитию сельского хозяйства в России. От начала государства до настоящего времени. СПб., 1888. С. 274.

3. ПСЗ РИ-2. Т. XLI. № 42899. - Января 18 (1866). Высоч. утв. мнение Гос. Совета., распубликованное 15 февраля. — 0 преобразовании общественного управления государственных крестьян, и о передачи сих крестьян в ведение общих губернских и уездных, а также по крестьянским делам учреждений.

4. Всероссийская выставка сельских произведений. Москва. 1864. Описание бывшей в Москве в 1864 г. Всероссийской выставки сельских произведений. СПб., 1865. С. 1-248.

5. Московское Общество Сельского хозяйства. Доклад Комиссия по устройству в Москве выставки произведений сельского хозяйства и сельской промышленности. М., 1863. С. 5.

6. Всероссийская сельскохозяйственная выставка. Харьков, 1887.0писание Всероссийской сельскохозяйственной выставки в Харькове 1887. Харьков, 1890. C. I, II, IX

7. Иллюстрированный альбом Первой Всероссийской мукомольной выставки в С.-Петербурге 25 янв. - 10 февр. 1909 г. Изд. ж-ла «Русский мельник». Киев, 1909. С. 3-4.

8. Никитин Ю. Как это было. Первая международная выставка в России // www/newizv.ru

9. Каталог Всероссийской выставки плодоводства, садоводства, огородничества и пр. Устраиваемая с 23 сентября по 11 октября 1890 года имп. Российским обществом садоводства. СПб., 1890; Первая Всероссийская выставка плодоводства, садоводства и огородничества // Сел. х0зяин. 1890 . № 49. С. 827-828; № 50. С. 845-846; № 51. С. 867-868.

10. Афанасович В.К. Всероссийская выставка садоводства, плодоводства, огородничества и проч., устроенная в 1890 г.: (с планом выставки) // Вестн. садоводства, плодоводства и огородничества. 1890. Нояб. С. 510-527; Дек. С. 543-562; 1891. Янв. С. 3-15; Февр. С. 67-76; Март. С. 122-130.

11. Черняев В.В. Первая выставка сушеных фруктов и овощей в Петербурге 31 октября и 2-6 ноября 1888 г. СПб., 1889. С. 1,4.

12. Всероссийский съезд пчеловодов и торговцев медом. Петербург. 1912. Всероссийская выставка пчеловодов, садоводства, огородничества и соприкаса- 
ющихся с ними отраслей. Петербург, 1912. Правила и программы. СПб., 1912.

13. ГУЗ и 3. Департамент Земледелия. Сельскохозяйственные выставки 1913 г. Вып. 1-3. СПб., 1913.

14. ГУ и 3. Департамент Земледелия. Список сельскохозяйственных выставок, предполагаемых к устройству в 1914 году. Вып.1. Сост. По сведениям на 15 февраля. 1914 г. СПб., 1914.

15. ГУЗ и З. Обзор деятельности за 1913 год. Ч.ІІ. СПБ.,1913. С.64

с Рогатко Сергей Александрович (rogatko1@yandex.ru).

Журнал «Современная наука: актуальные проблемы теории и практики»

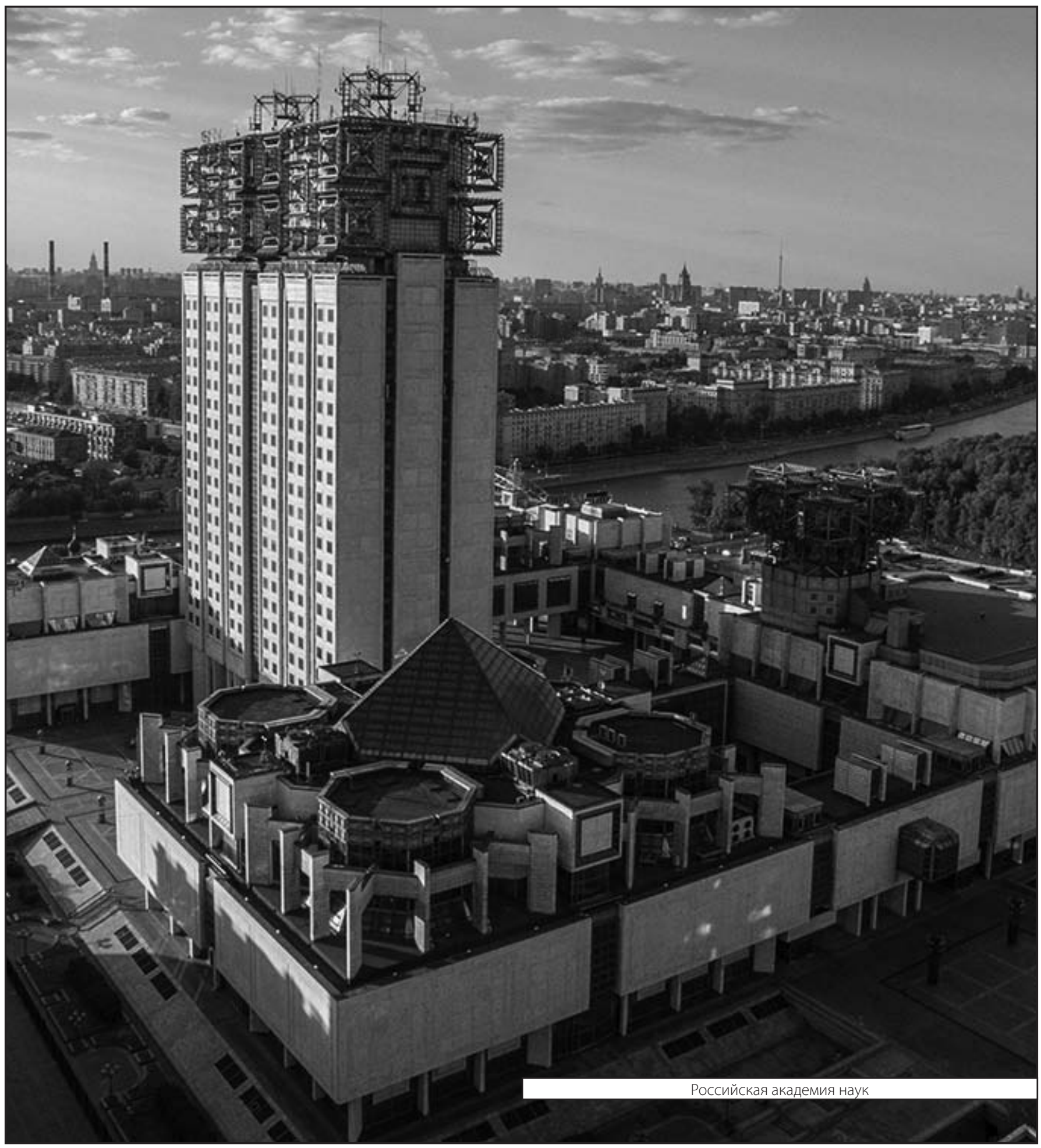

